\title{
Control of Trustee Discretion: THE Rule in RE HASTINGS-BASS
}

\author{
Simon Kerry
}

\begin{abstract}
This article examines the Court of Appeal decision in Pitt v Holt, and its implications for the rule in Re Hastings-Bass. The article argues that there are some inconsistencies between the post-Pitt position and other rules relating to the control of trustee discretion, particularly fraud on a power and the standing of trustees to sue in respect of their own breaches of trust. It also considers what is meant by saying a power is 'fiduciary', and argues that it is wrong to categorise the duty created by Pitt as fiduciary, as the Court of Appeal appears to do. Finally, it considers the reasons why settlors may wish to restore the pre-Pitt position by careful drafting, and presents a possible strategy by which they might do so.
\end{abstract}

\section{A. INTRODUCTION}

The Court of Appeal's judgment in Pitt v Holt-Futter v Futter ${ }^{1}$ represents a radical development of what was known as 'the rule in Re HastingsBass'. Lloyd LJ delivered a powerhouse judgment which comprehensively reinterpreted the rule from first principles. It is the purpose of this article to conduct a detailed examination of the operation of the new law, and ask if the post-Pitt position presents any discernable difficulties. It will be argued that the new scheme created by Pitt is deficient in a number of important respects.

In part B, the position of the law up to Pitt and the problems related to it will be outlined to contextualise the discussion. The key points of the judgment itself will also be discussed, including the two new categories identified by Lloyd LJ. In part C, this scheme will be examined in detail to try and work out how the two categories will apply in practice. Part D will consider how the new scheme dovetails with other doctrines, with a detailed examination of fiduciary doctrine in part E. Finally, in part F, the practical consequences of the decision will be considered - does it spell

\footnotetext{
" I am grateful to Professor Charles Mitchell, my dissertation supervisor, for his invaluable advice and feedback on this article. Responsibility for any errors or omissions remains, of course, with the author.

${ }^{1}$ [2011] EWCA Civ 197, [2012] Ch. 132 (henceforth collectively referred to as Pitt unless specified otherwise).
} 
change for settlors and trustees, or can the pre-Pitt position be restored with careful drafting?

\section{B. ORIGINS AND DEVELOPMENT}

\section{The Origin of the Rule}

Perhaps the greatest irony when considering 'the rule in Re HastingsBass' is that the case from which it originated did not fit the pattern of the cases that subsequently deployed the rule. The case of Re Hastings-Bass ${ }^{2}$ itself was mainly concerned with the question of whether it was possible, where part of a distribution was void for perpetuity and part not, to sever the void part of the distribution and proceed with the remainder. ${ }^{3}$ However, near the end of the judgment, Buckley LJ gave the following summary of principles in order, he thought, to add clarity to what was a long and complex judgment: ${ }^{4}$

To sum up the preceding observations, in our judgment, where by the terms of a trust (as under section 32) a trustee is given a discretion as to some matter under which he acts in good faith, the court should not interfere with his action notwithstanding that it does not have the full effect which he intended, unless (1) what he has achieved is unauthorised by the power conferred upon him, or (2) it is clear that he would not have acted as he did (a) had he not taken into account considerations which he should not have taken into account, or (b) had he not failed to take into account considerations which he ought to have taken into account.

It was part two of this statement of principle that was picked up on in the case of Mettoy Pension Trustees $v$ Evans. ${ }^{5}$ In that case, for the first time, the rule was applied to allow trustees to reverse a decision that they had made as a result of incorrect advice. It was accepted in principle that a deed altering the provisions for the distribution of a pension surplus could be invalid because the trustees had failed to realise that alterations were taking place, although the court declined to do so as it could not be shown that the pension trustees would have acted differently. This case held that

\footnotetext{
${ }^{2}$ [1975] Ch. 25.

3 ibid 35.

${ }^{4}$ ibid 41.

5 [1990] 1 WLR 1587, [1991] 2 All ER 513.
} 
there was a broad principle that could be applied wherever trustees had failed to take into account considerations which they ought to have taken into account, for whatever reason. ${ }^{6}$

This broad principle fell on fertile ground in the field of taxation. Since the case of Green v. Cobham, ${ }^{7}$ the courts have routinely accepted the argument that a trustee who makes a distribution and ignorantly triggers some adverse tax consequence can have the transaction set aside, even if they have had professional advice. The cases heard together in the Court of Appeal in Pitt $^{8}$ are typical examples of this class of case.

\section{Problems with the Old Law}

Before the Court of Appeal decision in Pitt, the law was in a state of some considerable disarray. It is worth highlighting a few of the problems, in order to get a sense of how badly comprehensive review was needed.

\section{(a) Lack of Clarity}

There were significant ambiguities in a number of areas, which created some difficulty in determining the precise scope of the rule and how it would be applied. These were some of the key debates.

\section{(i) Void vs. Voidable}

This was perhaps the most significant dispute in the cases. A large number were ambiguous as to the consequence of the engagement of the rule - did it render the transaction void, or merely voidable? As originally formulated in Re Hastings-Bass, the principle was that the court 'should not interfere" ${ }^{9}$ with the decision of the trustees unless the rule was infringed. The cases of Green $v$ Cobham ${ }^{10}$ and Abacus Trust Co. $v$ $N S P C C^{11}$ held that the transaction would be void; Abacus Trust Co. $v$ Barr $^{12}$ held that it was merely voidable. In Sieff $v$ Fox, ${ }^{13}$ Lloyd LJ held

\footnotetext{
${ }^{6}$ ibid at 555 .

${ }^{7}$ [2002] STC 820, [2000] 1 WTLR 1101.

${ }^{8}$ Pitt (n 1).

${ }^{9}$ Re Hastings Bass (n 2) 41.

${ }^{10}$ [2002] STC 820, [2000] WTLR 1101.

11 [2001] STC 1344, [2001] WTLR 953.

12 [2003] EWHC 114 (Ch.), [2003] Ch. 409.

13 [2005] EWHC 1312 (Ch.), [2005] 1 WLR 3811.
} 
obiter that the Barr view was attractive,${ }^{14}$ but not open to the judge in the light of the decision in Re Abraham's Will Trusts. ${ }^{15}$

These difficulties were exacerbated by a few cases in which bizarre intermediate positions were reached. In Futter at first instance, for example, the view was expressed that the result of the rule was that the transaction was void, but that nonetheless relief was discretionary at the instance of the court. ${ }^{16}$ This conclusion is perverse because the element of court discretion is usually taken to be the chief difference between void and voidable. ${ }^{17}$ That these observations were made "without the benefit of detailed argument ${ }^{18}$ makes them all the more imprudent.

\section{(ii) Would vs. Might}

On the question of how the trustee would have acted had he taken into account only and all relevant considerations, two approaches were distinguishable. The first held that it was necessary to show that the trustee would have acted differently, the second only that he might have. Examples of the former approach can be found in Hastings-Bass ${ }^{19}$ itself and Mettoy Pension Trustees $v$ Evans. ${ }^{20}$ The main cases taking the latter approach are Kerr $v$ British Leyland Trustees, ${ }^{21}$ Stannard $v$ Fisons Ltd, ${ }^{22}$ and $A M P U K v$ Barker. ${ }^{23}$

This debate was largely resolved in the case of Sieff $v$ Fox, where Lloyd LJ held that the 'might' standard would apply where the trustee was obliged to exercise his discretion, and 'would' would apply where he was not. ${ }^{24}$ Most commentators supported a division between the cases along these lines; ${ }^{25}$ however, doubt has also been expressed as to the

\footnotetext{
14 ibid [79].

15 ibid [81]; [1969] 1 Ch 463.

${ }^{16}$ [2010] EWHC 449 (Ch.), [2010] STC 982 [33].

${ }^{17}$ See eg David Hayton et al, Underhill \& Hayton: Law of Trusts and Trustees $\left(18^{\text {th }}\right.$ edn, Butterworths LexisNexis 2010) 856.

${ }^{18}$ Futter (n 16) [33].

${ }^{19}$ [1975] Ch. 25.

${ }^{20}$ [1990] 1 WLR 1587.

21 [2001] WTLR 1071.

22 [1992] IRLR 27.

23 [2001] PLR77.

24 [2005] EWHC 1312 (Ch.)[77].

${ }^{25}$ Charles Mitchell, 'Reining in the rule in Re Hastings-Bass' (2006) 122 LQR 35, 40;

David Hayton, 'Pension Trusts and Traditional Trusts: drastically different species
} 
relevance of the compulsory nature of the power or not, since "the actual exercise of it, as an act, is not different in quality or degree from the exercise of a [non-compulsory] power. ${ }^{26}$ The answer to this question was therefore never completely settled.

\section{(iii) Fault}

Most cases consistently held that there was no need to demonstrate that the trustee had been at fault in any way in order to allow recovery. The cases most strongly for this proposition are those where the failure to take into account only and all relevant considerations is a result of incorrect advice; in these cases, there is no question that the trustee had done anything wrong. Perhaps the cleanest example of this is Sieff $v$ Fox ${ }^{27}-$ the trustees had acted entirely properly, taken advice on the relevant fiscal consequences, and acted diligently upon it; the advice had simply been wrong. Nonetheless, the transaction was void under the rule.

However, this no-fault approach has not been universal. In the case of Abacus Trust Co. $v$ Barr, ${ }^{28}$ a trustee made a distribution of $60 \%$ of a fund when the settlor's true intention had only extended to $40 \%$, as a result of a mistake made by an intermediary. Adopting a duty-led analysis, the court said: ${ }^{29}$

If the Trustee has in accordance with his duty identified the relevant considerations and used all proper care and diligence in obtaining the relevant information and advice relating to those considerations, the Trustee can be in no breach of duty and its decision cannot be impugned merely because in fact that information turns out to be partial or incorrect.

In that case, it was held that such a breach had been established, because the carelessness of the intermediary could be imputed to the trustee.

of trust' [2005] Conv. 229; John Mowbray et al, Lewin on Trusts $\left(17^{\text {th }}\right.$ edn, Sweet \& Maxwell 2007) 1080.

${ }^{26}$ Hayton et al (n 17) 855.

${ }^{27}$ [2005] EWHC 1312 (Ch.).

28 [2003] EWHC 114 (Ch.), [2003] Ch. 409.

${ }^{29}$ ibid [23] (Lightman J). 


\section{(iv) Public Law Principles}

Some cases have sought to develop the rule by drawing analogies with public law principles. In particular, courts have used these analogies to try and determine to what extent it is legitimate for them to substitute their own judgment for that of the trustee in exercising his discretion. This blending of the principles of public and private law was referred to somewhat positively in the case of Edge $v$ Pensions Ombudsman: ${ }^{30}$

It seems to us no coincidence that courts, considering the exercise of discretionary powers by those to whom such powers have been entrusted (albeit in different contexts), should reach similar and consistent conclusions; and should express those conclusions in much the same language.

However, the appropriateness of importing these principles into the private law context has been questioned. In Underhill \& Hayton: Law of Trusts and Trustees, it is pointed out that the focus of the public law and trust law enquiries are different - 'The former focuses on the individual's opportunity to be heard ... [the latter] on the information available to the person making the decision. ${ }^{31}$ Furthermore, the authors argue, the public law analogy runs the risk that an inexperienced judge might attempt to import other elements of public law, whose applicability might be more suspect. $^{32}$

\section{(b) Lack of Consistency with Mistakes Made by Individuals}

Another problem was a lack of consistency between the approach taken to Hastings-Bass type failures in the trust context, and similar mistakes made by individuals. This point is made particularly by Bhandari, in the context of decisions made with adverse tax consequences. ${ }^{33}$ While noting that individuals might be able to rely on the doctrines of rescission or rectification, she observes that these remedies are significantly more limited than the rule in Hastings-Bass. She says: ${ }^{34}$

\footnotetext{
${ }^{30}$ [2000] Ch. 602, [1999] 4 All ER 546, 567-8.

${ }^{31}$ Hayton et al (n 17) 851; cf $R v$ Charity Commissioners, Ex p. Baldwin [2001]

WTLR 137.

${ }^{32}$ Hayton et al (n 17) 851.

${ }^{33}$ Monica Bhandari, 'Tax Advantages for Bungling Trustees' (2009) eJournal of Tax Research 7(1) 54.

${ }^{34}$ ibid 62.
} 
The Hastings-Bass principle allows a transaction to be undone in cases where an individual would have no success. Thus, there is a difference in the extent to which trustees and individuals can undo transactions for tax purposes.

In Sieff v Fox, Lloyd LJ, with some academic support, ${ }^{35}$ argued that this differential treatment is justified on the basis that 'trustees are dealing with assets which are not their own. ${ }^{36}$ This argument, however, is not accepted by Bhandari, who argues that the relationship of trustee and beneficiary should have no relevance to a transaction between the trustee and some third party - since both the trustee and individual are legal owners of the property in question, the treatment of both should be exactly the same. Any protection the beneficiary requires should be provided through the rules regulating that relationship. ${ }^{37}$

\section{A New Path - Pitt v Holt}

Against this backdrop of dispute and confusion, the cases of Pitt $v$ Holt and Futter $v$ Futter were heard together in the Court of Appeal. The facts were of the by now standard Hastings-Bass mould. In the first, Mr. Pitt, who had been injured in a serious road accident, had received substantial compensation in 1994. Mrs. Pitt decided, on advice, to put the money into a settlement trust. This trust was executed in a way that gave rise to a significant inheritance tax charge - estimated at some $£ 100,000$ by the time of Mr. Pitt's death in $2007 .{ }^{38}$ However, this was not realised until 2003. The prime purpose of the trust being to provide for Mr. Pitt's welfare, no thought appeared to have been given to the tax consequences - if it had been, the tax could very easily have been avoided. ${ }^{39}$

The second case concerned a straightforward tax avoidance device that went wrong. Mr. Futter was the beneficiary of an offshore trust which held significant stockpiled gains. On advice, he triggered some losses which he intended to set off against the gain that would be made when the stockpiled gains were brought onshore. Unfortunately, his advisors overlooked section 2(4) of the Taxation of Chargeable Gains Act 1994,

\footnotetext{
${ }^{35}$ See eg Hayton et al (n 17) para 61.22, especially text accompanying fn 9.

${ }^{36}$ Pitt (n 1) [85].

${ }^{37}$ Bhandari (n 33) 68.

${ }^{38}$ Pitt (n 1) [9].

${ }^{39}$ [2010] EWHC 45 (Ch), [2010] 1 WLR 1199 [12].
} 
which prevented offsetting in this way. When the distributions were duly made under the scheme, therefore, a significant tax charge was incurred. ${ }^{40}$ In both cases, it was held at first instance that the Re Hastings-Bass rule applied and the relevant transactions would be declared void.

Lloyd LJ, who gave the leading judgment in the Court of Appeal, took the opportunity to undertake an extensive re-appraisal of the principles applicable in these cases. This was not his first such attempt; in the case of Sieff $v$ Fox, which he heard sitting as a judge at first instance, he had attempted to resolve some of the inconsistencies in the law and reach a more settled position. However, he had been bound to follow the previous first instance authority and so the impact of his decision was somewhat limited. This time his approach was much more radical.

\section{(a) The Judgment}

Lloyd LJ built up his judgment in stages, which it will be helpful to examine in turn. The first was his observation that only the decision of $R e$ Hastings-Bass was binding upon him; ${ }^{41}$ all others were heard only at first instance. This is an important point, since it allowed him significant leeway when it came to interpreting the case law.

The second was to subject Re Hastings-Bass itself to a thorough reappraisal, in search of the true ratio of the case. ${ }^{42}$ A critical part of the case, in his view, was Buckley LJ's treatment of what had been termed the Revenue's 'fourth submission', namely that: ${ }^{43}$

in order to exercise the power of advancement by making a sub-settlement the trustees must weigh the benefits to the advancee under the sub-settlement against the other interests affected and for that purpose must have a proper understanding of the effect of the sub-settlement. If they do not, they have not validly exercised their power at all.

This submission, Lloyd LJ argued, had been 'rejected in terms' by Buckley LJ in Hastings-Bass. ${ }^{44}$ Taking these two points together, he had now cut almost the entire body of law relating to the Hastings-Bass rule

\footnotetext{
${ }^{40}$ Futter (n 16) [8] - [17].

${ }^{41}$ Pitt (n 1) [5], [46].

42 ibid [46]-[67].

43 ibid [50] citing Re Hastings-Bass (n 2) 29.

${ }^{44}$ ibid [58].
} 
off from its origins and from any binding authority, and had a free hand to set about restructuring it in his own way. ${ }^{45}$

Thirdly, he turned to his exposition of the law as correctly understood. ${ }^{46}$ Building on the judgment in $B a r r,{ }^{47}$ he recognised two classes of case that were previously dealt with under the Hastings-Bass rule. First: ${ }^{48}$

The purported exercise of a discretionary power on the part of trustees will be void if what is done is not within the scope of the power.

His Lordship gave some examples of this type of exercise: $:^{49}$

There may be a procedural defect, such as the use of the wrong kind of document, or the failure to obtain a necessary prior consent. There may be a substantive defect, such as an unauthorised delegation or an appointment to someone who is not within the class of objects. Cases of a fraud on the power are similar to the latter, since the true intended beneficiary, who is not an object of the power, is someone other than the nominal appointee. There may also be a defect under the general law, such as the rule against perpetuities, whose impact and significance will depend on the extent of the invalidity.

The second category he described as follows: ${ }^{50}$

By contrast with the types of case to which I have referred at [96], above, if an exercise by trustees of a discretionary power is within the terms of the power, but the trustees have in some way breached their duties in respect of that exercise, then (unless it is a case of a fraud on the power) the trustees' act is not void but it may be voidable at the instance of a beneficiary who is adversely affected.

Finally, he turned to the application of this new structure to the cases before him. In respect of both, it was held that the fiduciary duty to take into account only and all relevant considerations had been discharged,

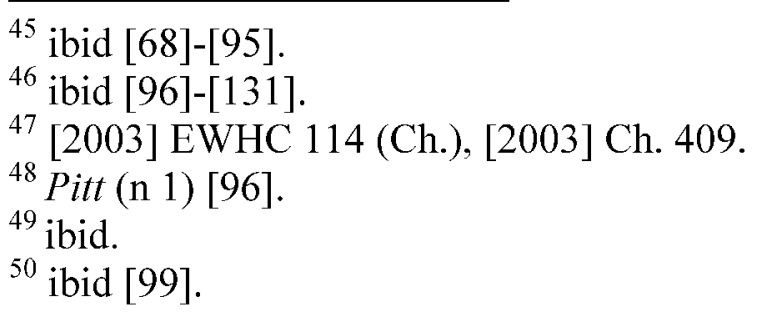


since both fiduciaries had consulted advisors and acted upon their advice. $^{51}$

\section{ANALysing the New Regime}

\section{The scope of the Two Categories}

If Lloyd LJ intends his new scheme to be used as a practical tool in deciding how to dispose of cases, it is necessary to consider how exactly cases will be divided between them. As will be seen, there are some unresolved issues surrounding the precise scope and interaction of the two categories.

\section{(a) The First Category}

Lloyd LJ's view was that the first category would be of limited use, and would only be engaged in a few of the most extreme cases. He said: ${ }^{52}$

In principle, cases where an act done by trustees which appears to be within their powers can be held to be void ought in my judgment to be kept to a minimum, just as at common law the cases where a transaction is void, rather than voidable, are few and far between.

He supported this view on the basis of the damage to stability in commercial arrangements that would be done if acts taken could be shown many years later to have no effect. By contrast, if the act were merely voidable, then the equitable defences exist to safeguard justice in the individual case. While clearly not ideal in terms of legal certainty, it is submitted that this greater flexibility is the more desirable option.

\section{(i) Matthews' Alternative Analysis}

However, Paul Matthews has presented an interpretation of the rule that might lead to a different outcome. ${ }^{53}$ In his view, the requirement to take into account all and only relevant considerations is an implied term in the trust deed; it is the default position (which the settlor can modify) that, in order to constitute an exercise of the power held by the trustee, only and

\footnotetext{
${ }^{51}$ ibid. As regards Futter v Futter [139]; as regards Pitt v Holt [163].

52 ibid [101].

${ }^{53}$ Hayton et al (n 17) 852-862.
} 
all relevant considerations must be taken into account. ${ }^{54}$ On this view, every case where not only and all relevant considerations are taken into account is an exercise of power outside the trust deed - the first category identified by the Court of Appeal. Every case will therefore result in the transaction being void, and the second category will have no role at all. Against this analysis, two points may be made.

The first point is that this type of reasoning was clearly not in line with the expectations of the Court of Appeal. Lloyd LJ was explicit in the view that the first category would be confined within narrow limits (see above), and so expansion along the lines outlined would be, at the very least, surprising.

The second point is that Matthews' analysis, even as an explanation of the previous case law, is flawed. We saw above that one of the main features of the older cases has been a focus on the question of causation; would (or might) the trustee have acted differently? But Matthews' analysis seems to leave no room for this point; once the trustee has failed to reach his decision in the proper manner, it is void, regardless of the outcome of the decision. He writes: ${ }^{55}$

Hence, in the Hastings-Bass context, if the conduct stipulates for by the settlor is a decision with due formality, the trustee-appointer being required to have taken into account all and only relevant considerations, and the trustee has not done so, the conduct has not occurred and so the power has not been exercised.

No reference at all is here made to the causal element that so occupied the judges in the earlier cases. Although not strictly relevant to the new position taken by the Court of Appeal, this point does undermine his claim that implied terms are crucial to understanding what is happening in these cases.

\section{(b) The Second Category}

It is not only the first category that Lloyd LJ envisaged having a limited scope. In giving his judgment, Lloyd LJ said: ${ }^{.6}$

\footnotetext{
${ }^{54}$ ibid especially para 61.22 .

55 ibid 858.

${ }^{56}$ Pitt (n 1) [129].
} 
If the principle had been applied which I have set out above, then it seems likely that a number of the cases decided at first instance would have been decided differently ... But it is not a useful exercise for present purposes to re-examine the earlier cases generally, and I will say no more on that subject.

This makes clear that the second category would be more limited in its application than the old rule had been, but is less helpful on the question of the precise extent of the duty. The relevant control factor here is the question of what 'ought' to be taken into account by the trustee, ${ }^{57}$ but no clear guidance is given on what that might comprise.

The strategy adopted was to decide what ought to have been taken into account on a case-by-case basis. Lloyd LJ said: ${ }^{58}$

It is not possible to lay down any clear rule as to the matters which trustees ought to take into account when considering the exercise of a power of advancement or some other dispositive discretionary power. Circumstances will differ a great deal from one trust to another, and even within one trust they may change from time to time or according to the nature of the particular exercise which is under consideration.

In similar terms, Mummery LJ spoke of an inquiry by the court into the nature of the duty and whether or not there had been a breach 'in the particular case. 59

However, while this approach may well suit an appeal court applying an ex post facto review, it is perhaps less helpful for a trustee looking for guidance as to what he must take into account when making his decision. ${ }^{60}$ It is submitted that more should have been done to assist those in that situation.

Some hints of an alternative approach are present in the judgment; the Court set out some categories of considerations that 'may' be relevant to the decision. Lloyd LJ dealt in some detail with fiscal consequences, ${ }^{61}$

\footnotetext{
${ }^{57}$ This was specifically discussed by Lloyd LJ: ibid [114]-[118].

58 ibid [118].

59 ibid [238].

${ }^{60}$ This failure to improve on the previous law has been noted in the online update to John McGhee, Snell's Equity (32 ${ }^{\text {nd }}$ edn, Sweet \& Maxwell 2011) para 10-033 and text accompanying fn 160 .

$<$ http://www.snellsequity.co.uk/Chapter.aspx?PartID $=10 \&$ ChapterID $=53>$ accessed on 2 July 2012.

${ }^{61}$ Pitt (n 1) [115]-[116].
} 
as that had direct bearing on the case before him. He also noted several other categories that may be relevant, namely the wishes of the settlor and the 'wishes, circumstances and needs' of the beneficiary, and one consideration that should not be taken into account - personal disapproval. ${ }^{62}$ This type of indication will be of far more use to the trustee who needs to know how to exercise his discretion on an everyday basis, since he will at least know what he should be looking at. It is submitted that it would be desirable if this type of lead were developed in future into a more comprehensive group of considerations that, in general, trustees should take account of.

Lloyd LJ rejected this categorisation approach, however, on the basis that the duty needed to be flexible in order to take into account the range of different circumstances that might apply to different trusts, and even within the same trust over time. In particular, he referred to the following example: ${ }^{63}$

It might be different if what was proposed was the release from the trust of a relatively modest sum of capital to meet an extremely urgent need of one of several beneficiaries. In such a case it might not be necessary to undertake the same degree of enquiry and examination as it would be if the proposed transaction affected a very large proportion of the trust fund, or was not required as a matter of extreme urgency.

No doubt this is a concern, but with respect this flexibility could be accommodated while at the same time giving some general guidance. The example is a somewhat extreme one, and it would be perfectly sensible to set out some general guidelines as to what would be required in the normal case, but leave it open to the trustee to argue that, in these particular circumstances, the duty was more restricted.

The courts have found it possible to lay down such general guidance that maintains flexibility in respect of other duties on trustees. In Re Baden (No. 2), ${ }^{64}$ for example, the Court of Appeal felt able to do so with respect to how the question of distribution should be approached where there was a broad power covering a large class of beneficiaries. Sachs LJ,

\footnotetext{
62 ibid [114].

63 ibid [117].

${ }^{64}$ [1973] Ch. 9.
} 
for example, fleshed out the duty in the following way, referring to the previous judgment of Lord Wilberforce: ${ }^{65}$

When looked at in the context of the rest of the speech this particular passage does not seem to me to cause any difficulty. In my judgment it refers to something quite different, to a need to provide a list of individuals or to provide a closely accurate enumeration of the numbers in the class: it relates to that width of the field from which beneficiaries may be drawn and which the trustees should have in mind so that they can adapt to it their methods of discretionary selection. Assessing in a businesslike way "the size of the problem" is what the trustees are called on to do.

This general guidance was given despite the same concern over differences between trusts in different circumstances: ${ }^{66}$

The word "range," however, in that context has an inbuilt and obvious element of considerable elasticity, and thus provides for an almost infinitely variable range of vision suitable to the particular trust to be considered.

In this case, then, some general guidance could be given on the scope of the duty, while recognising that there would be some flexibility for individual circumstances. In light of this approach being adopted in other cases, it is difficult to agree with the strong conclusion that clear guidance for the trustees would be 'not possible'.

\section{INCONSISTENCY WITH OTHER AREAS}

Despite the appearance that Lloyd LJ's new scheme fits harmoniously with other doctrine, there are several areas in which the scheme is inconsistent with prior case law. Two examples will be examined here.

\section{Fraud on a Power}

In his judgment in Pitt, Lloyd LJ set up a bipartite distinction between cases where an exercise of a power would be void (where it was outside the power or in breach of the law) ${ }^{67}$ and those where it would be voidable

\footnotetext{
65 ibid 20.

${ }^{66}$ ibid 20 (Sachs LJ).

${ }^{67}$ Pitt (n 1) [96].
} 
(where it was exercised in breach of duty). ${ }^{68}$ On its face, this distinction neatly categorises all duties relating to the exercise of trust powers.

However, difficulties with the scheme begin to arise if one attempts to examine in detail how each doctrine would fit within the taxonomy. A good example of this is fraud on a power, which Lloyd LJ explicitly discusses and appears to identify with category one: ${ }^{69}$

Cases of a fraud on the power are similar to [an appointment to someone who is not within the class of objects], since the true intended beneficiary, who is not an object of the power, is someone other than the nominal appointee.

Lloyd LJ clearly conceptualises fraud on a power as an extension of the inquiry as to the scope of the power that has been conferred, and so 'similar' to the construction of the terms of the power. The difficulty with this analysis is that the case law has by no means unambiguously treated the fraud doctrine in this way. Admittedly, support for Lloyd LJ's view can be found in earlier cases, such as Vatcher $v$ Paull, ${ }^{70}$ where the court said: ${ }^{71}$

[Fraud in this context] means that the power has been exercised for a purpose, or with an intention, beyond the scope of or not justified by the instrument creating the power.

However, more modern discussions have moved away from the language of scope and towards that of an 'improper exercise' of a power. In Hillsdown Holdings plc v Pensions Ombudsman, ${ }^{72}$ Knox $\mathbf{J}$ introduced as a modern alternative to fraud on a power the term improper use of the power for a collateral purpose. ${ }^{, 73}$ And similar language was used by the New Zealand Court of Appeal in the case of Wong $v$ Burt: ${ }^{74}$

The word "fraud" here denotes an improper motive, in the sense that a power given for one purpose is improperly used for another purpose.

\footnotetext{
68 ibid [99].

69 ibid [96].

${ }^{70}$ [1915] AC 372.

71 ibid 378.

72 [1997] 1 All ER 862.

73 ibid 883.

${ }^{74}$ [2005] 1 NZLR 91[28].
} 
This more modern terminology is the more appropriate, for two reasons. First, because the focus of the inquiry in the fraud cases is as to the subjective intentions of the trustee. Describing the fraud doctrine as related to 'improper motives' focuses the mind of the court on the appropriate question, namely what the trustee was intending by making the distribution. Relating the inquiry to scope, on the other hand, gives the misleading impression that the proper focus is on detailed technical consideration of the terms of the trust and on 'reading in' limitations by the trustee. Second, because a number of rules relating to the fraud doctrine make little sense from the perspective of the scope analysis. For instance, as was pointed out in Wong $v$ Burt, it is the trustee's intention that is key to working out if the exercise is invalid, not the substance of the exercise. If the trustee's intention is to benefit a non-object the exercise is void; if the trustee has no such intention, but the transaction does in fact benefit a non-object, the exercise is valid. ${ }^{75}$ The intention-led 'improper motives' description points clearly towards this conclusion. The scope analysis, however, is more uncomfortable with this rule, because the distribution is not, in itself, outside the power conferred by the trust deed.

Furthermore, this more modern analysis is supported by authorities that have clearly treated the question of fraud on a power as entirely separate from the construction of the terms of the power. An early example is Henty $v$ Wrey, ${ }^{76}$ in which Lindley LJ explicitly separated the two questions, and warned that amalgamating them may lead to 'considerable confusion'. ${ }^{77}$ Similarly, in Hillsdown Holdings Knox J, referring to the decision in Re Vauxhall Motors Pension Fund, Bullard v Randall $^{78}$ said that ' $[\mathrm{t}]$ here is absolutely no trace of [fraud on a power] having been argued and it is clear that Browne-Wilkinson V-C did not regard himself as doing more than decide a question of construction', again indicating that construction of terms is a wholly separate enquiry to fraud on a power. ${ }^{79}$

\footnotetext{
75 ibid [30], citing Vatcher v Paull (n 70).

${ }^{76}$ (1882) 21 LR Ch.D. 332.

77 ibid 355.

${ }^{78}$ [1989] 1 PLR 49.

${ }^{79}$ [1997] 1 All ER 862, 883.
} 
The conclusion, then, is that it is inapposite to place fraud in the first of Lloyd LJ's categories. The mindset-led approach indicates that the fraud doctrine has more in common with the old Hastings-Bass rule than with the construction of the terms - in both fraud on a power and Hastings-Bass, the exercise is void because the trustee made his decision on the basis of facts that should not properly influence his judgment. In the words of Mummery LJ, both relate to the manner in which a power is exercised, rather than its existence or extent. ${ }^{80}$ This point can be strengthened by noting that a fraud can, in most cases, be recast as an infringement of the Hastings-Bass rule - where the trustee appoints to an object knowing that the object will pass the property on to a non-object (a fraud), and he takes into account that knowledge in making his decision, which he ought not to do.

All of which presents a serious problem for Lloyd LJ's analysis, since he placed fraud within category one but cases previously covered by Hastings-Bass into category two. How can this difficulty be reconciled?

The solution is to recognise that Lloyd LJ's classification scheme is confined to cases that fall within the Pitt pattern. That is, where the trustee has failed to take into account only and all relevant considerations, the effect might be either that the exercise is outside the scope of the power, or is a breach of duty - but that does not preclude other categories of defective exercise existing in other areas. This approach has the advantage that it allows the fraud doctrine to exist in the intermediate class between Lloyd LJ's two categories, dealing with improper motives by the trustee but nonetheless resulting in the exercise of the power being entirely void.

There is some textual evidence from Pitt to support this analysis. In discussing the first category, Lloyd LJ remarked only that the fraud doctrine is 'similar' to an exercise outside the scope of the power, and did not directly equate the two. Although he discussed fraud on a power at length, this discussion was not in relation to its placement within his scheme, but was rather to clear up a collateral point in relation to the void/voidable debate. ${ }^{81}$ Nowhere did he say that his two categories were supposed to represent a comprehensive scheme for all rules relating to

\footnotetext{
${ }^{80}$ Pitt (n 1) [233].

81 ibid [97]-[98].
} 
trustee discretion. Furthermore, at several points he made reference to rules, such as the rule against self-dealing, that implied that they were external to his scheme ${ }^{82}$ - it appears he at least countenanced the possibility that his new structure was not all-inclusive.

In any event, since both of the cases before him fell within his second category and so were dealt with by the duty question, ${ }^{83}$ his more general comments in relation to the first were strictly unnecessary for his decision, and may be taken to be obiter. To the extent that they appear to suggest that fraud on a power belongs in category one, it is submitted that they are incorrect and should not be followed.

\title{
2. Standing to Sue
}

In relation to cases within his second category, Lloyd LJ said: ${ }^{84}$

\begin{abstract}
One practical consequence, if I am right, is that if in future it is desired to challenge an exercise by trustees of a discretionary power on this basis, it will be necessary for one or more beneficiaries to grasp the nettle of alleging and proving a breach of fiduciary duty on the part of the trustees. Only rarely would it be appropriate for the trustees to take the initiative in the proceedings...
\end{abstract}

He then gave one example of when it 'may' be appropriate for the trustees to take action: ${ }^{85}$

[I]f (as in Abacus $v$ Barr) they need to seek directions from the court if a beneficiary alleges breach of trust but does not bring his own proceedings.

The clear indication is that some dissatisfied beneficiary must initiate the process of questioning the trustee's decision, even if it is the trustee themselves that begins the formalised court process as a result. This signal of disapproval at trustees bringing actions against their own breaches was not made on the basis of authority; rather, Lloyd LJ seems to have seen it as no more than a 'practical consequence' of his finding that it was necessary to show a breach of fiduciary duty. ${ }^{86}$

\footnotetext{
82 ibid [100].

${ }^{83}$ See footnotes $50-51$ and accompanying text.

${ }^{84}$ Pitt (n 1) [130].

${ }^{85}$ ibid.

${ }^{86}$ ibid [127], [130].
} 
Although passed off as an uncontroversial statement of principle, this conclusion runs counter to a number of cases in which it has been held that the trustees are entitled to sue upon their own default. The context in which this most frequently arises is where one trustee sues his co-trustees for a breach in which all participated. A good example of this type of case is Butler $v$ Butler. ${ }^{87}$ In that case, two trustees, $\mathrm{P}$ and $\mathrm{D}$, had sold land belonging to $\mathrm{D}$ to a builder, who financed the purchase by mortgaging the land back to the trustees. $\mathrm{P}$ later brought an action against D seeking a personal indemnity for losses arising from the fact that the land was insufficient security. It was held, affirming the decision at first instance, ${ }^{88}$ that $\mathrm{P}$ could not make D liable where he was a party to the breach. However, it was indicated that, notwithstanding P's participation, he could bring an action to recover the trust property that had found its way to D's hands: ${ }^{89}$

It was quite open to the Plaintiff in this case, in a suit properly constituted, to have alleged the insufficiency of this security either with or without an alleged breach of trust, and the refusal of his co-trustee to call in the security and to see that the moneys were placed out in proper investments. It was open to him to have filed a bill for that purpose.

This principle is still very much alive, and has been applied in significantly more modern cases. In the Australian case of Young $v$ Murphy, ${ }^{90}$ the standing of trustees and company directors to bring actions against themselves or their predecessors was extensively reviewed by the Court of Appeal.

In that case, the court expressly rejected arguments that the beneficiaries needed to play an enhanced role in bringing the action. It was held that the long-standing rule is that the beneficiary is only required to bring the action themselves where there is a dispute between the beneficiaries, ${ }^{91}$ as in that case there are grounds to say that the trustee will not properly represent the interests of them all. ${ }^{92}$ The discussion on this

\footnotetext{
87 (1877-78) LR 7 Ch.D. 116.

88 (1877) 5 Ch.D. 554 (Fry J).

89 Butler (n 87) 120 (Baggally LJ).

${ }^{90}$ [1996] 1 VR 279.

91 ibid 285.

92 ibid 283.
} 
point is particularly relevant, because it is made in reference to English law from 200 years ago, and so the reasoning is directly applicable in English cases.

The standing question arose recently in the English courts in Bracken Partners Ltd. v Gutteridge. ${ }^{93}$ In that case, an action was brought on behalf of a company, EGL, that had knowingly received property obtained in breach of fiduciary duty, and was therefore liable under the doctrine of knowing receipt. ${ }^{94}$ Although the central question in that case was whether EGL had sufficient interest in the property to participate in the claim, it is significant that EGL's breach of fiduciary duty was not seen as a bar to them having standing. ${ }^{95}$ This appears to be the opposite conclusion to that reached by Lloyd LJ in Pitt. What is particularly striking about the Gutteridge case is that the main judgment was given by Mummery LJ, who also sat on Pitt - despite this, in the latter case he felt able to support Lloyd LJ's conclusion on this point, saying: ${ }^{96}$

(e) a claim for breach of fiduciary duty would not normally be made by a fiduciary (as has happened in practice under the Hastings-Bass rule), but rather against a fiduciary by a person claiming to be an object of the power;

In all of these authorities, then, there was no question of there being any difficulty with the trustee suing on the basis of their own breach. It is difficult to see why in Pitt the position has moved, without discussion, to such action being taboo.

\section{(a) A Duty to Sue?}

Some cases have gone even further, and have tended to indicate that not only can a trustee sue for his own breach, but has a positive duty to do so. This arose first in Baynard $v$ Woolley ${ }^{97}$ Rejecting an argument that the plaintiff trustee could not sue for a wrong in which he had participated, the court said: ${ }^{98}$

\footnotetext{
93 [2003] EWCA Civ 1875, [2004] 1 BCLC 377.

94 ibid [14].

95 ibid [16].

${ }^{96}$ Pitt (n 1) [231], (emphasis in the original).

9752 ER 729; (1855) 20 Beav. 583.

98 ibid 585 (footnotes omitted; emphasis added).
} 
This Court would undoubtedly compel the other trustee to make good the breach of trust, though the Plaintiff may have concurred in it, it being his duty to secure the trust fund for the benefit of the cestuis que trust, and to such a suit the trustees alone are necessary parties. The books are full of cases, in which the trustees have called on their co-trustees to replace funds, notwithstanding they have themselves been guilty of acts not in accordance with their duty.

It is worth noting in particular that this passage goes significantly beyond stating that trustees are entitled to sue, and appears to suggest they have a positive duty to do so. This reasoning was echoed by the Australian Court of Appeal in Young: ${ }^{99}$

the trustee's right and duty to sue is part of his duty to get in the trust estate, which includes rights of action against co-trustees or former trustees ...

Again, these cases were not referred to by Lloyd LJ, so we have no explanation of why the position in Pitt was any different.

\section{(b) The Policy Reasoning}

Even if Lloyd LJ's position on standing is difficult to relate to the previous case law, is it nonetheless justifiable on policy grounds? The underlying consideration in his mind seems to have been to prevent the supposedly pernicious practice of trustees bringing actions against themselves without the commitment of the beneficiaries; he stated that his new principle would require beneficiaries to 'grasp the nettle' of proving breach of fiduciary duty. ${ }^{100}$ Similar observations were made at first instance in Futter $v$ Futter by Norris J, who said that the possibility of trustees complaining of 'untrustee-like behaviour' by themselves in order to set their own acts aside raised the possibility 'that the development of the rule may have been diverted from its true course. ${ }^{101}$

However, it is submitted that denying standing to trustees is not an appropriate course to take to prevent this practice, for three reasons. First, it can be questioned whether there is really a problem with trustees suing upon their own breach. As noted above, cases such as Young have held that a trustee will be allowed standing in similar situations since it is

\footnotetext{
${ }^{99}$ [1996] 1 VR 279, 284 (emphasis added).

${ }^{100}$ Pitt (n 1) [130].

101 [2010] EWHC 449 (Ch) [2].
} 
ultimately in the interests of the beneficiaries to allow the trustees to get the property back into the trust. ${ }^{102}$ If the money were in principle recoverable in a case following Pitt, and the trustees ready and willing to act, an insistence on requiring the beneficiaries to initiate the action would be puzzling - it would be rather more efficient to allow the trustees to proceed, especially considering that they will often be professionals and perhaps more qualified to do so than the beneficiaries.

Secondly, it could be argued that the restriction of standing was designed to restrict the number of cases of this type that were brought. The courts do seem to have been somewhat burdened by the millstone they created; Norris $\mathrm{J}$ in Futter referred exasperatedly to 'another' application by trustees seeking to undo their actions and avoid tax consequences. ${ }^{103}$ However, this prompts the second point; this burden has been considerably lessened by the other changes made by Pitt. Most of the cases ${ }^{104}$ under the old rule concerned trustees who were poorly advised; all such cases have now been diverted away from the rule by Lloyd LJ's imposing a requirement that a breach of duty be shown. He himself explicitly discussed the professional advice, and was of the view that where trustees had sought advice which had been given incorrectly breach of duty would not be made out. ${ }^{105}$ The standing restriction therefore seems somewhat superfluous if limiting the number of cases was the primary concern.

Thirdly, the ability of the trustees to take the action is inherent in their role as actors in the interests of the beneficiaries. Again, this point was the foundation of the findings in Young; Brooking $\mathrm{J}$ quoted Porter M.R. in Carson v Sloane ${ }^{106}$ : 'If one of the [beneficiaries] could follow the trust, why cannot the trustee who represents them all? ${ }^{107}$ To make this point slightly differently, as was indicated in Young, ${ }^{108}$ suing in respect of one's own breach is merely an action in line with the continuing duty of

\footnotetext{
102 Young (n 90) 282 (Brooking J).

103 [2010] EWHC 449 (Ch) [2].

104 For example Futter v Futter [2010] EWHC 449 (Ch); Pitt v Holt [2010] EWHC 45

(Ch); Sieff v Fox [2005] EWHC 1312 (Ch.); Abacus Trust Co v Barr [2003] EWHC

114 (Ch.).

${ }^{105}$ Pitt (n 1) [125].

${ }^{106}$ (1884) 13 LR Ir 139.

107 (1996) 1 VR 279, 283.

108 ibid.
} 
the trustee to get in the trust property. If this ongoing duty is to be curtailed for some reason in particular circumstances, it is for Lloyd LJ to justify why the status quo has been altered, as well as why significant authority has been departed from. As indicated above, such a justification is absent from Pitt.

\section{E. Fiduciaries}

\section{Fiduciary Duties}

In setting out his second category of case, Lloyd LJ frequently referred to the duty to take into account only and all relevant considerations as a fiduciary duty. ${ }^{109}$ The difficulty with this use of terminology is that there is significant debate over the boundaries of fiduciary duties, and whether or not it is possible for a fiduciary to owe a non-fiduciary duty.

The relevance of this distinction, as discussed by Lord Millett in Bristol and West Building Society v Mothew, goes beyond that of clarity in legal taxonomy. ${ }^{110}$ The practical implication is principally felt at the stage of remedies. Put broadly, demonstrating a breach of a common law duty is subject to certain requirements, such as a remoteness limitation on causation etc. These limitations do not apply with the same rigour where the breach of duty is fiduciary. ${ }^{11}$

The difficulty with the judgment in Pitt is that, being primarily concerned with the void/voidable debate, Lloyd LJ's references to a fiduciary duty appear to have been an example of an 'unthinking resort to verbal formulae. ${ }^{, 12} \mathrm{He}$ appears to have conflated the duty of skill and care and fiduciary duties, despite the sharp distinction drawn by Lord Millett in Mothew: ${ }^{113}$

It seems to me that Mrs Pitt fulfilled any duty of skill and care she was under by looking for advice to her solicitors acting in the litigation, either to advise her or to see that she got whatever advice she needed from another source, such as

\footnotetext{
${ }^{109}$ Pitt (n 1) [127].

${ }^{110}$ [1998] Ch. 1, 17.

111 cf. John Dyson Heydon, 'Are the Duties of Company Directors to Exercise Care and Skill Fiduciary?' in Simone Degeling and James Edelman (eds), Equity in

Commercial Law (Thomson LBC 2005), esp. 189-191.

${ }^{112}$ Mothew (n 110) 16.

${ }^{113}$ Pitt (n 1) [163].
} 
from Frenkel Topping. In those circumstances, I cannot accept that, in entering into the two deeds on 1 November 1994, Mrs Pitt can be said to have been acting in breach of her fiduciary duties owed to Mr Pitt.

Lacking a clear position within the debate over the term fiduciary, it will be necessary to consider in some detail the competing sides in this debate if we are to understand whether the duty is properly termed fiduciary or not. Much of the literature relates to other duties, owed by different types of fiduciaries, but is relevant in order to work out some basic principles for distinguishing fiduciary from other duties. Once these principles have been worked out, they can be applied to the duty identified in Pitt.

\section{Two Approaches}

The principal debate in this area is over how the word 'fiduciary' is to be employed. The first approach, which may be termed 'historical', is to examine all the duties owed by persons who have been identified by the courts as holding a fiduciary position, and from an examination of their position in relation to the principal divine the purpose for which fiduciary duties are imposed. Getzler, for example, has adopted an analysis led by a desire to ensure that fiduciaries are appropriately deterred from acting against the interests of their principal, since the principal is in a uniquely vulnerable position to the power of the fiduciary. ${ }^{114}$ Historical analyses frequently focus upon the consequences of a breach of fiduciary duty, and discussions of policy motivations for applying the stricter fiduciary rules to different breaches of duty. ${ }^{115}$

The second, more modern approach, is to focus on those duties that are peculiarly owed by fiduciaries, and then examine those duties in order to come to a coherent understanding of fiduciary doctrine. This was pioneered by Finn in his classic analysis of fiduciary duties, Fiduciary Obligations, where he made a comprehensive attempt to classify and analyse the duties owed by fiduciaries. He outlined his approach as follows: ${ }^{16}$

\footnotetext{
114 Joshua Getzler, 'Am I My Beneficiary's Keeper? Fusion and Loss-Based Fiduciary Remedies' in Simone Degeling and James Edelman (n 111), esp. 271.

115 ibid 263; Heydon (n 111), esp. 220-225.

${ }^{116}$ Paul D. Finn, Fiduciary Obligations (The Law Book Company Ltd. 1977) 2.
} 
It is not because a person is a 'fiduciary' or a 'confidant' that a rule applies to him. It is because a particular rule applies to him that he is a fiduciary or confidant ...

This mantle has been taken over more recently by Conaglen, who takes a slightly different approach - of the duties owed by fiduciaries, he selects only those exclusive to them, and then attempts to understand what distinguishes these duties from all others. He describes this as the 'Mothew principle', since it is inspired by the observations of Lord Millett in the Mothew case. His (somewhat controversial ${ }^{117}$ ) conclusion is that the only exclusively fiduciary duties are those of to avoid conflicts or to make profits from the fiduciary position, ${ }^{118}$ and that these duties exist to 'provide a subsidiary and prophylactic form of protection for nonfiduciary duties." 119

We might summarise the difference between the two approaches by saying that the historical approach looks for a fiduciary label first, and then considers what duties the fiduciary owes, whereas the modern approach is to look for exclusively fiduciary duties, and then attach the label to whoever owes them. Each approach has its problems - the question is, which is overall the more convincing approach.

\section{Problems with Historical Analyses}

Conaglen identifies two problems with the historical approach ${ }^{120}$. First, it now appears to be out of step with the courts. He gives numerous examples of the acceptance of the Mothew principle, not only in this country, but around the common law world. A failure to adopt the new approach will ultimately lead to a theory that is out of touch with what the courts are doing on the ground. This is a fair point, but its strength should not be over-emphasised. If the Pitt case teaches us nothing else, it is that the law can be set down the wrong path and we should always be alive to the possibility that the orthodoxy is incorrect.

Secondly, it results in a lack of conceptual clarity in understanding the role of a fiduciary, and the justifications for the peculiar legal

\footnotetext{
${ }^{117}$ For criticism see Rebecca Lee, 'In Search of the Nature and Function of Fiduciary Loyalty: Some Observations on Conaglen's Analysis' (2007) 27 OJLS 327.

118 Mattew Conaglen, Fiduciary Loyalty (Hart Publishing 2010) Ch. 3.

119 ibid 4.

${ }^{120}$ ibid 21.
} 
consequences attendant upon a breach of fiduciary duty. ${ }^{121}$ Attempting to incorporate all of the duties owed by a fiduciary into the fiduciary concept results in a definition that is broadly stated and somewhat unhelpful. For example, Getzler characterises fiduciary duties as responding to a dependency formed from the difficulty of monitoring the fiduciary, and the special vulnerability of the principal. ${ }^{122}$ But this definition of 'fiduciary' is not sufficiently precise to set any outer limits. Anyone in a contractual relationship, for example, is vulnerable to a breach by the other party, since it might cause them significant loss. And the negligence duty of care is arguably a similar response to vulnerability as fiduciary doctrine - pedestrians are vulnerable to the actions of a negligent driver, for instance. This point seems implicitly accepted in Getzler's ${ }^{123}$ and Heydon's ${ }^{124}$ argument that the beneficiaries are as vulnerable to the want of care of their fiduciary as they are their disloyalty - however, neither explain why these contract or tort duties are not fiduciary by their definition. In attempting to incorporate all duties owed by fiduciaries, their definitions are too expansive to be helpful.

This second point can be pushed significantly further - without developing a sound understanding of what makes fiduciaries different from other actors, arguments based on the historical approach can fail to be even internally coherent. A good illustration of this is the argument presented by JD Heydon. ${ }^{125}$ His chapter is useful because it not only adopts a somewhat historical approach to the definition of fiduciary, but also appears to be somewhat anti-definitional, in that it attacks the Mothew approach without clearly putting in place an alternative conception of the meaning of fiduciary.

This failure has far-reaching consequences for Heydon's argument, because without this reference point, his argument inevitably becomes inconsistent. In particular, he falsely concludes that some parts of the law are anomalous because he fails to observe them from a fixed standpoint. A good example of this is where he argues that failing to regard the duty

\footnotetext{
121 ibid

${ }^{122}$ Getzler (above n 114) 271.

123 ibid 241.

${ }^{124}$ Heydon (above n 111) 217.

125 ibid 185.
} 
of care and skill leads to an 'imbalance of remedies and wrongs. ${ }^{126} \mathrm{He}$ points out that the duty of good faith, which requires culpable fraud, and the no profit duty, which can be breached innocently, are both usually regarded as fiduciary duties. It would therefore be illogical for the duty of care and skill, which requires an intermediate culpable state, to not be regarded as fiduciary also. ${ }^{127}$ This conclusion may be correct; but if no definition of fiduciary is offered, it is impossible to say whether or not mental culpability is the correct yardstick to be applying.

An analogy may be drawn with the general law. Contracts, which impose strict liability for breach of duty, contain obligations that are entered into voluntarily. Negligence creates liability at a higher standard, requiring a breach of standard of care, and unjust enrichment does so at a lower standard, requiring no breach of any duty - in both cases liability is imposed by law. Applying the yardstick of voluntariness, it seems illogical that liability is imposed by the law in situations of a negligent breach and of no breach, but that strict liability, which falls between the two, must be undertaken voluntarily through a contract. The fallacy is the same; the imbalance is only apparent, created by a failure to understand why we distinguish between contracts, torts and unjust enrichment.

Returning to fiduciaries, the reason for 'imbalance', Heydon points out, is obvious if one adopts Conaglen's definition of fiduciary duties the no profit duty is peculiarly fiduciary because it is directed to procuring the diligent execution of other duties, whereas the duty of care and skill is not. ${ }^{128}$ That Conaglen is able to explain this apparent anomaly while Heydon is not illustrates the weakness of the historical approach.

\section{Problems with the Mothew Approach}

The Mothew analysis displaces all duties that are not exclusive to fiduciaries and banishes them into other realms of the law. However, not all commentators regard this as an appropriate step, at least not without modification. For instance, Getzler, identifying vulnerability as the heart of the fiduciary obligation, ${ }^{129}$ argues that the fiduciary and contractual

\footnotetext{
126 ibid 225.

127 ibid.

${ }^{128}$ Conaglen (n 118 ) Ch. 4. It should be noted that Conaglen also regards the duty of good faith as non-fiduciary, so for him this imbalance simply does not arise: 40-4.

${ }_{129}$ Getzler (above n 114) 272.
} 
relationships should be expanded to cover much of the ground that, after Hedley Byrne \& Co Ltd $v$ Heller \& Partners Ltd, ${ }^{130}$ is covered by the tortious duty of care. ${ }^{131}$

The central claim of this argument is that there is a distinction between the duty of care applied to fiduciaries and non-fiduciaries which should be recognised. However, there is nothing in Conaglen's argument that rejects this possibility; indeed, he specifically accepts that different duties of care can apply to different actors: ${ }^{132}$

[T]he argument advanced here is not dependent on the existence of a 'monotonic' duty of care... Duties of care do not need to be identical amongst all ... actors for them to be grouped together and described as duties of care.

On closer inspection, then, it appears that there is no substantial disagreement between Getzler and Conaglen on this point - both accept that the duty of care can be modified in respect of fiduciaries.

One potential source of genuine disagreement is over the question of whether or not the duty of care applicable to fiduciaries is peculiar and unique to them. If the duty of care simply flexes to meet the factual demands of each case, then there is no problem with Conaglen's classification of the duty of care as non-fiduciary. However, if it appears that the existence of a fiduciary relationship will always lead to the adoption of a particular standard, then that standard will be peculiar to fiduciaries and will pass the Mothew test as a duty owed exclusively by a fiduciary. This would render Conaglen's expulsion of the duty of care from the category of fiduciary duties erroneous.

In order to make this argument successfully, it would be necessary to show that the same standard of care is applied to all fiduciaries, and that it is materially different from that applied at common law. However, there is significant evidence that that is not the case. Conaglen ${ }^{133}$ gives the example of Lagunas Nitrate Co. Ltd. v Lagunas Syndicate ${ }^{134}$ where it was specifically accepted that the standard of care applicable to a director

\footnotetext{
${ }^{130}$ [1964] AC 465.

${ }^{131}$ Getzler (n 114) 271.

${ }^{132}$ Conaglen (n 118) 101.

133 ibid 15.

${ }^{134}$ [1899] 2 Ch. 392.
} 
would not be the same as that applied to a trustee. ${ }^{135}$ This indicates that the duty of care flexes to particular circumstances, as Conaglen's model allows, but there is no peculiarly fiduciary notion of the 'duty of care'.

\section{Summary of Principles}

The foregoing analysis has accepted Conaglen's definitional approach as the more attractive, following Mothew. The only duties that are fiduciary are those that are owed exclusively by fiduciaries, namely the duty to avoid conflicts of interests and the duty not to make profit from the position of fiduciary. Other duties, such as the duty of care, are nonfiduciary. Their content might be altered by the existence of a fiduciary relationship, but not in a sufficiently uniform way to give them an independent identity as fiduciary duties.

\section{Applying the Framework}

Returning to our discussion of the new duty in Pitt, the question remains, is it properly termed a fiduciary duty?

Adopting Conaglen's approach, the critical question in assessing whether or not the duty is fiduciary is whether or not it is owed exclusively by fiduciaries. On this test, the duty to take into account only and all relevant considerations is not fiduciary - many examples can be given of this duty arising in other contexts. Clearly, the duty to take into account all relevant considerations will form part of the duty of care owed by advisors in negligence - in Pitt $v$ Holt for instance, the same failure to take into consideration the effect of the taxation legislation resulted in a tort claim against the solicitors. ${ }^{136}$ And to take a very different example, in the case of $R v$ Secretary of State for the Home Department, Ex. p. Bentley $^{137}$ it was held that the Home Secretary's decision not to grant a pardon was reviewable because he had failed to take into account all the forms such a pardon could take.

\footnotetext{
135 ibid 435.

${ }_{137}^{136}$ [2010] EWHC 45 (Ch) [14].

137 [1994] QB 349.
} 


\section{Conclusion}

Lloyd LJ's description of the duty to take into account only and all relevant considerations as fiduciary was erroneous. When that term is properly understood, it cannot be applied to the duty identified in Pitt.

\section{F. Drafting out of PItT}

The final remaining question from the judgment in Pitt is the practical consequences of the decision. Lloyd LJ appeared to consider that the decision would have wide-ranging consequences on cases, particularly those in his second category. However, there is a possibility that settlors might prefer the old scheme, and employ careful drafting in order to ensure that defective decisions by their trustees result in void, and not merely voidable, dispositions. Why might a settlor choose to do so, and what methods could be employed?

\section{Commercial Motivation}

The key reason why the settlor might wish to prescribe voidness is in order to give greater protection to his beneficiaries, by allowing them to avoid pernicious consequences regardless of the interference of third party rights or any other consideration. This protective argument was one of the main justifications that was given for the voidness rule under HastingsBass, ${ }^{138}$ and the drafting suggested below would have precisely the same effect.

This additional protection may be particularly important in cases that involve trustees who have received professional advice. Under the new law, as set out by the Court of Appeal in Pitt, for a breach to fall within category two and trigger voidability it is necessary to show a breach of the relevant duty. However, where incorrect advice has been received and acted on by the trustee (as was the case in Pitt), there will be no such breach. The beneficiary will therefore be left out of pocket as a result of the innocent mistake of the trustee. A settlor may be dissatisfied with this situation, and wish to prescribe voidness in order to throw the risk of any such mistake onto third parties dealing with the trustee.

As a partial answer to this concern, several cases have pointed out that the beneficiary would be able to pursue a negligence action against

${ }^{138}$ Hayton et al (n 17) 859. 
the advisor who gave the negligent advice. This observation was repeated most recently in Pitt. However, this might also face its own difficulties; in particular, it might be that it is impossible to show that the advisor acted negligently, for instance where the mistake arises because of a clerical error introduced by an intermediate communication system. Indeed, weaknesses in the alternatives were noted in Pitt $^{139}$ and, while Lloyd LJ did not feel that they forced him to reconsider his conclusions on principle, they might well deter a concerned settlor from relying upon his scheme and compel him to draft in his own safeguard.

Finally, settlors may wish to avoid Lloyd LJ's second category in order to ensure that their trustees have standing to sue in respect of their mistakes. As has been discussed above, the position in relation to standing within category two is somewhat unclear; Pitt indicated that it would be inappropriate for a trustee to bring such an action, but this may be regarded as inconsistent with earlier cases. ${ }^{140}$ In category one, the trustee is on firmer ground; it is reasonably clear from cases such as $R e$ Abraham's Will Trusts ${ }^{141}$ that in the pre-Pitt case law the trustees could bring an action in order to determine if what they have done is within the terms of the trust. However, the reasoning which lead to the conclusion that it would be inappropriate for a trustee to bring an action seems to be limited to cases where a breach of fiduciary duty is in issue, i.e. cases within category two. ${ }^{142}$ This may seem an unimportant point, but experience of the pre-Pitt case law indicates that this was an option deployed by many trustees, so it would seem that there is some value in ensuring that issues of mistaken transactions can be resolved without involving the beneficiaries.

\section{Achieving these Aims}

If a settlor wished to obtain these advantages, there a number of ways he could go about it. One possible mechanism for doing so is suggested by the analysis of Professor Matthews. It will be recalled that his analysis of the pre-Pitt position was that the declaration that the transaction was void made perfect sense as an application of an implied term within the trust

\footnotetext{
${ }^{139}$ Pitt (n 1) [128].

${ }^{140}$ See text accompanying footnote 78 et seq.

${ }^{141}$ [1969] 1 Ch 463.

${ }^{142}$ Pitt (n 1) [130].
} 
deed. ${ }^{143} \mathrm{He}$ used this analysis to defend the view that voidness was the correct outcome in Hastings-Bass cases. Logically, precisely the same outcome could be achieved if an express term to the same effect were placed in the trust deed, for instance:

It shall be a condition precedent to the exercise of this power that the trustee has, in making his decision, taken into account all and only relevant considerations.

The effect of such a term would prima facie be to change all failures to take into account only and all relevant considerations into acts outside the scope of the power, rendering them void as per Lloyd LJ's category one.

It will also be recalled that Matthews' argument was criticised, on the basis that it would be inconsistent with Pitt to make such a supposition and that his analysis offered no account for the central role of causation in the previous case law. ${ }^{144}$ However, none of these criticisms go so far as to deny the effectiveness of an express provision to the same effect. It would not be inconsistent with Pitt to give effect to such a clause, since exercises of power specifically outside the terms of the trust deed were identified by Lloyd LJ as within category one and therefore void. The point about causation is irrelevant, since it is a point merely about the lack of fit with the analysis in previous cases; at best, it serves to illustrate that causation would form no part of the inquiry if such a clause were inserted into the trust deed. And the implausibility of implying such a term is plainly irrelevant in circumstances where the term is expressly included.

\section{Reaction of the Courts}

Even if a carefully drafted trust deed might place all mistakes in category one, the question remains as to whether the courts would accept the effectiveness of such a clause. There might be some reluctance to allow settlors to override the scheme that Lloyd LJ so carefully worked out.

However, it seems likely the attempt would be successful. Settlors generally have freedom of trust, and so may make whatever provisions they like in their own deeds. This freedom seems particularly extensive; for instance, settlors may modify or exclude the liability of their trustees

\footnotetext{
${ }^{143}$ See text accompanying footnote 48 et seq. 144 ibid.
} 
to a considerable extent. The only thing the courts will not permit them to do is exclude liability for fraud. ${ }^{145}$ If the courts were to take a radically different position in relation to cases within Pitt, that would need considerable justification.

The court might take the view that the parties should not be allowed to circumvent the important policy considerations that have influenced the structure created, and any attempt to do so will be declared ineffective. However, usually declaring a transaction as contrary to policy is reserved only for the most extreme cases, such as immorality or illegality, and the courts have exhibited a reluctance to expand its role. ${ }^{146}$ Furthermore, such a course would be at odds with past decisions that have given parties freedom of trust even in the face of potentially overriding policy objections. The example of excluding trustee liability is again useful here - in the case of Armitage $v$ Nurse, significant judicial disapproval was poured over the practice of excluding trustee liability: ${ }^{147}$

At the same time, it must be acknowledged that the view is widely held that these clauses have gone too far, and that trustees who charge for their services and who, as professional men, would not dream of excluding liability for ordinary professional negligence should not be able to rely on a trustee exemption clause excluding liability for gross negligence ...

However, ultimately the Court felt it was not its role to interfere: ${ }^{148}$

If clauses such as [the exclusion clause in this case] are to be denied effect, then in my opinion this should be done by Parliament, which will have the advantage of wide consultation with interested bodies and the advice of the Trust Law Committee.

The resilience of the freedom of trust argument in the face of a foolproof trust is significantly strengthened when it is recalled that the policy argument in that case - distribution of risk and liability between the parties - is essentially the same as that in the case of Pitt.

\footnotetext{
145 Armitage v Nurse [1998] Ch. 241.

${ }^{146}$ See, in the context of contract, Printing \& Numerical Registering Co. v Sampson (1875) LR 19 Eq. 462; and for a general overview see Edwin Peel, Treitel on the Law of Contract (12 ${ }^{\text {th }}$ edn, Sweet \& Maxwell 2007) para. 11-105.

${ }_{147}$ [1998] Ch. 241, 256.

148 ibid.
} 


\section{G. Conclusion}

The judgment in Pitt has radically altered the landscape of court control of trustee discretion. There is significant cause to doubt whether all the problems with the old rule have been solved; just a few problems with the new position have been outlined here. It is perhaps apt that the editor of Snell has, in a recent revision, replaced the section entitled 'the rule in $R e$ Hastings-Bass' with a new one called 'the rule in Pitt'. ${ }^{149}$ The controversies of the old law are gone, but only to be replaced by new ones.

\section{H. PostsCRIPT}

On 1 August 2011, permission was granted for an appeal in the case of Pitt $v$ Holt to the Supreme Court. At the time of going to print, that appeal had not been heard, and so it remains to be seen whether the position outlined by Lloyd LJ will be substantially altered, or the problems outlines above dealt with.

${ }^{149}$ McGhee (n 60). 